\title{
System Thinking Approach to Increase Eco-Friendly Maize Production to Support Food Security
}

\author{
Ulfa Emi Rahmawati, Erma Suryani, and Raulia Riski \\ Departemen of Information System, Institut Teknologi Sepuluh Nopember, Surabaya \\ e-mail: erma.suryani@gmail.com
}

\begin{abstract}
Abstrak-Food security is a high priority issue for sustainable global agricultural development both quantitatively and qualitatively. Maize is one of the most important food crops in the world after rice and wheat. The biggest contribution of maize production in Indonesia comes from East Java Province, which is $25,60 \%$. Maize production is changing due to increased consumer demand, increased input costs, concerns about food security and environmental impacts. Climate conditions of marginal land areas (drought) and the use of chemical fertilizers continuously have negative impacts on the amount of production, food security, and soil quality (environment). This situation is dangerous because it will affect the income from farming. Based on these problems, in this study a system dynamics perspective study will be conducted to develop a conceptual model (Causal Loop Diagram) to increase the eco-friendly maize production to support food security. The results of the study are conceptual models that have some important information regarding internal and external factors that affect the productivity and production of eco-friendly maize. The conceptual model produced can be used by the government and stakeholders for decision making in developing strategies and policies related to eco-friendly maize cultivation systems to support food security. Further research can be done by developing several scenarios to predict the state of the maize farming system in the future.
\end{abstract}

Keywords - Causal Loop Diagram, Eco-Friendly, Food Security, Maize, System Dynamics.

\section{INTRODUCTION}

M AIZE (Zea mays L.) is one of the most important food crops in the world after rice and wheat [1]. Maize is the second most-produced cereal in the world after rice, maize is planted on every continent except Antarctica [2]. Maize is used as animal feed, as human food, and as a raw material in the industry [3]. Maize production centra in Indonesia during 20142018 was distributed in ten provinces with a total contribution of $85,36 \%$ of the total production, with the largest contribution of national maize production coming from East Java Province, about 25,60\% (Figure 1) [1].

However, the agricultural production of maize has changed due to increased consumer demand, increased of input costs, concerns about food security, and environmental impacts [4]. Weather and climate change are indicated to be one of the causes of maize crop failure and low productivity [5]. This phenomenon has a direct impact on increasing abiotic pressure

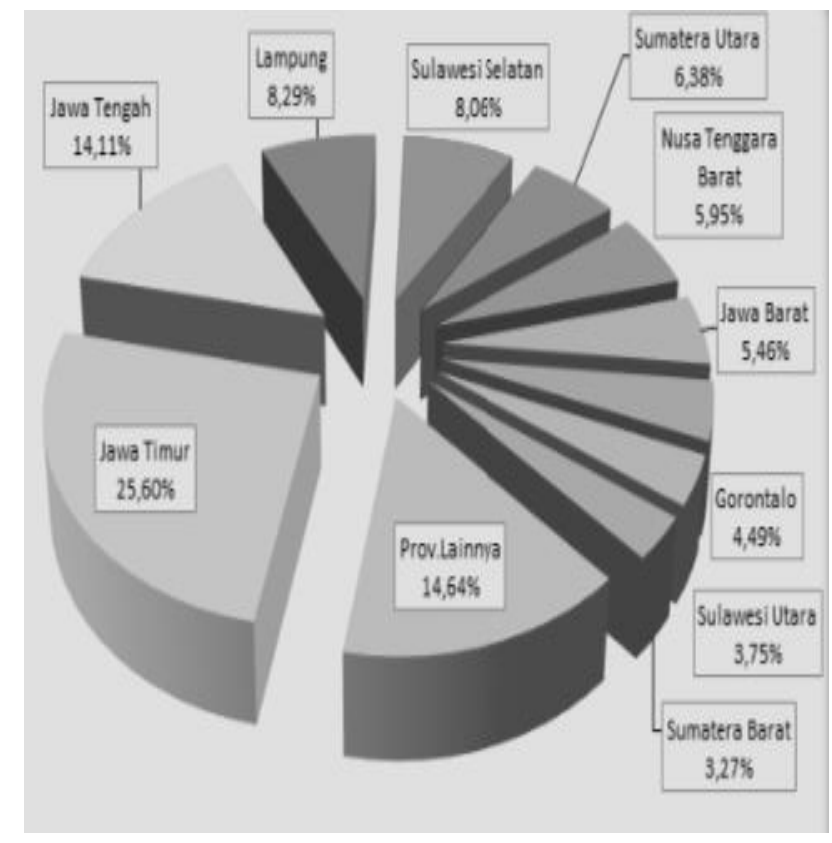

Figure 1. The Average Contribution of Maize Production Center in Indonesia.

on agricultural land, such as increasing marginal land area (drought) [6]. The level of drought is directly related to the poor formation of seeds in maize, which inhibits the growth and development of maize [7]. The continuous use of inorganic fertilizers in maize farming also has a negative impact on soil productivity and the environment [8]. The continuous use of inorganic chemical fertilizers has led to the degradation of agricultural land, where one of its negative impact is the decrease in the amount of agricultural production [9]. Therefore, the challenges for the sustainability of modern agriculture include increased of agricultural costs, wasted a lot of energy and environmental pollution [10]. This can result in decreased productivity and agricultural production of maize commodities, as well as results in unstable farmer income.

Climate conditions of marginal land area (drought) and the continued use of chemical fertilizers resulting in the decline of maize productivity and production, this is dangerous for food security of maize commodities. Food security is a high priority issue for sustainable global agricultural development both 
The $6^{\text {th }}$ International Seminar on Science and Technology (ISST) 2020

July $25^{\text {th }}, 2020$, Institut Teknologi Sepuluh Nopember, Surabaya, Indonesia

Table 1.

Boundary adequacy of maize cultivation

\begin{tabular}{|c|c|c|c|c|}
\hline Sub Model & Endogenous & Unit & Exogenous & Unit \\
\hline & Maize seed effect & $\%$ & Rainfall effect & $\%$ \\
\hline Land productivity & Irrigation effect & $\%$ & Pest \& disease effect & $\%$ \\
\hline (Ton / ha) & Fertilizer effect & $\%$ & Humidity effect & $\%$ \\
\hline & Labor effect & $\%$ & Temperature effect & $\%$ \\
\hline $\begin{array}{l}\text { Maize production } \\
\text { (Tons) }\end{array}$ & $\begin{array}{l}\text { Land productivity } \\
\text { Total Harvest land area }\end{array}$ & $\begin{array}{c}\text { Ton / Ha } \\
\mathrm{Ha}\end{array}$ & & \\
\hline $\begin{array}{c}\text { Gross income (Rupiah } \\
\text { / Ha) }\end{array}$ & $\begin{array}{l}\text { Maize production } \\
\text { Land productivity }\end{array}$ & $\begin{array}{c}\text { Ton } \\
\text { Ton / Ha }\end{array}$ & Market price & Rupiah / kg \\
\hline Net income (Rupiah) & $\begin{array}{l}\text { Gross income } \\
\text { Cultivation cost }\end{array}$ & $\begin{array}{l}\text { Rupiah / Ha } \\
\text { Rupiah }\end{array}$ & & \\
\hline & & & Industry demand & Ton \\
\hline Total demand (tons) & & & $\begin{array}{l}\text { Animal feed demand } \\
\text { Consumption demand }\end{array}$ & $\begin{array}{l}\text { Ton } \\
\text { Ton }\end{array}$ \\
\hline Fulfillment ratio (\%) & Maize production & Ton & Total demand & Ton \\
\hline Consumption demand & & & Consumption per capita & $\begin{array}{c}\mathrm{Kg} / \text { capita / } \\
\text { year }\end{array}$ \\
\hline $\begin{array}{l}\text { Industry demand } \\
\text { (Ton) }\end{array}$ & & & $\begin{array}{l}\text { Total population } \\
\text { Animal feed industry } \\
\text { Non-animal feed } \\
\text { industry }\end{array}$ & $\begin{array}{l}\text { People } \\
\text { Ton } \\
\text { Ton }\end{array}$ \\
\hline $\begin{array}{l}\text { Total population } \\
\text { (People) }\end{array}$ & & & $\begin{array}{c}\text { Birth rate } \\
\text { Death rate } \\
\text { Immigration rate } \\
\text { Emigration rate }\end{array}$ & $\begin{array}{l}\text { Dmnl } \\
\text { Dmnl } \\
\text { Dmnl } \\
\text { Dmnl }\end{array}$ \\
\hline $\begin{array}{l}\text { Total harvest land area } \\
\qquad(\mathrm{Ha})\end{array}$ & Expansion plant area & $\mathrm{Ha}$ & Reduce plant area & $\mathrm{Ha}$ \\
\hline $\begin{array}{c}\text { Expansion plant area } \\
\text { (Ha) }\end{array}$ & & & Expansion rate & $\mathrm{Ha}$ \\
\hline $\begin{array}{c}\text { Reduce plant area } \\
\text { (Ha) }\end{array}$ & & & Reduce rate & $\mathrm{Ha}$ \\
\hline
\end{tabular}

quantitatively and qualitatively [11]. The issue of food security and farm environment is more important than an interest in improving the taste of food and having modern agriculture [12]. Therefore, the emergence and diversity of food security issues have become a global concern, especially its inseparable relationship with human health $[13,14,15,16]$.

Research conducted by Dimkpa et al [17] related to drought, states that the effects caused by drought on food crops can be overcome by fertilizing using organic fertilizers that rich in $\mathrm{Zn}$ and $\mathrm{ZnO}$ to increase food production and quality in adverse conditions. Thus, it can be concluded that drought problems can be handle by using organic fertilizer. This statement is supported by research conducted by Wang et al [18] which provides affiliation variables in agricultural cooperatives, organic fertilizer subsidies, and agricultural size that play a positive role in influencing farmers' choices for organic fertilizers instead of chemical fertilizers. Long-term fertilization causes a decrease in soil quality, crop yields, and impedes agriculture [19], so for these concerns, organic farming is highly recommended [12] as a good way to increase crop yields, and friendly to the environment at the same time.

The use of organic fertilizer is in contrast to research conducted by Sadeghi et al [20] which states that the selection of superior genotypes (hybrid KSC 647) in terms of grain yield can show lower environmental damage, increase productivity, and reduce the environmental impact of production. This can also be an alternative to increasing eco-friendly maize production. However, even though organic plants are promoted as eco-friendly products in several countries, they have also sparked huge controversy in developing countries facing food security and low agricultural productivity [12]. In addition, optimizing land use can also promotes food security [11].

From several studies on agriculture on drought land, the use of eco-friendly organic fertilizers, and the use of hybrid seeds, the whole study has one goal in common namely to increase agricultural production. The number of changes in system behavior over time, complex system dynamics, and the presence of feedback could provides the latest information about the state of the system which will then can be used to produce decisions [21]. From these characteristics and problems, this study uses a system dynamics perspective to understand the real condition of maize farming systems and develop systems thinking to increase maize production. The results of this study are maize cultivation models based on the real conditions captured and modeled. This paper is organized as follows. Section 1 explains the introduction. Section 2 explains the method. Section 3 presents the results and discussion. And finally, in Section 4 the conclusion is made.

\section{METHODS}

Climate conditions of marginal land area (drought) and the continued use of chemical fertilizers could result in the decline of maize productivity and production, this is dangerous for food security and has an impact on farmer's income that would become unstable. To be better prepared to face uncertainty and 


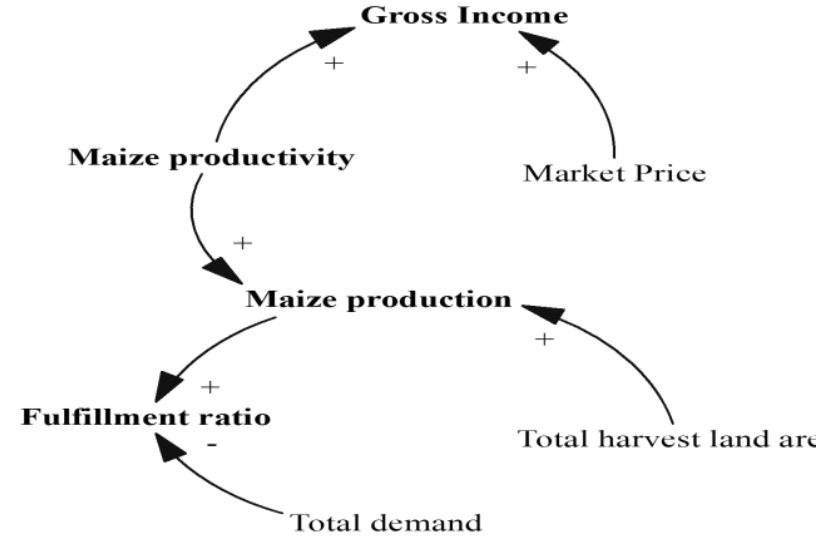

Figure 4. The basic pattern of the system.

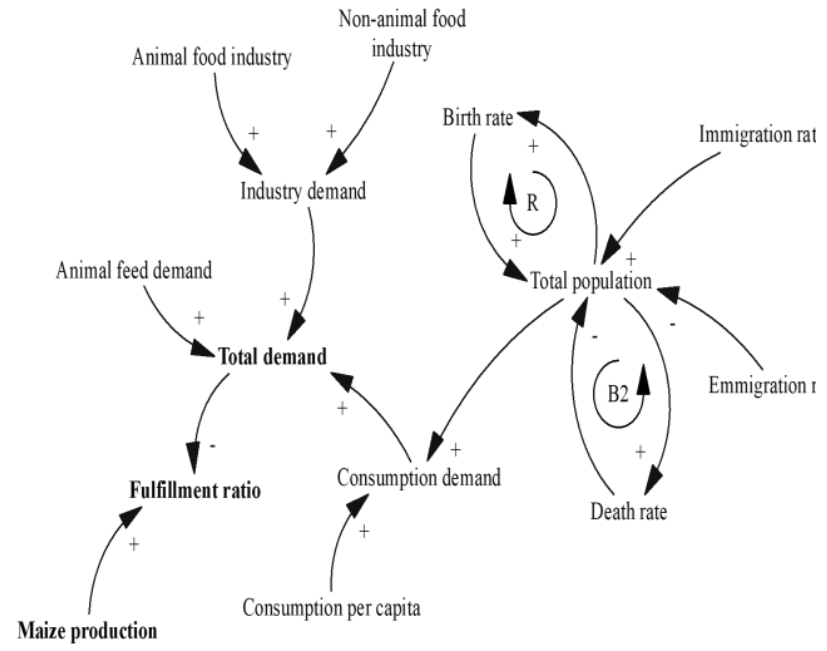

Figure 5. Maize demand and fulfillment ratio sub-model.

disruption in the future, stakeholders need to develop further knowledge of the maize farming system, through a structure and complexity of feedback that dominates to test robust and integrated system-based solutions [22]. From many methodologies and tools available to deal with this type of problem, system dynamics modeling is used because of its ability to explicitly address problems with systemic and dynamic drivers, which enables an increased understanding of problems and behaviors that arise [23, 24]. The system dynamics simulation approach is considered suitable because it is based on feedback in each part of the system that affects other parts [25].

\section{A. Modeling}

Modeling is an aid in decision making. Model is a representation of a real system. It is defined as a depiction of a system that has been restricted. This restricted system is a system that includes all concepts and variables that interconnected with the specified dynamic problem[26]. Model development can be done using several ways, such as elaboration, analogy, and dynamic [21].

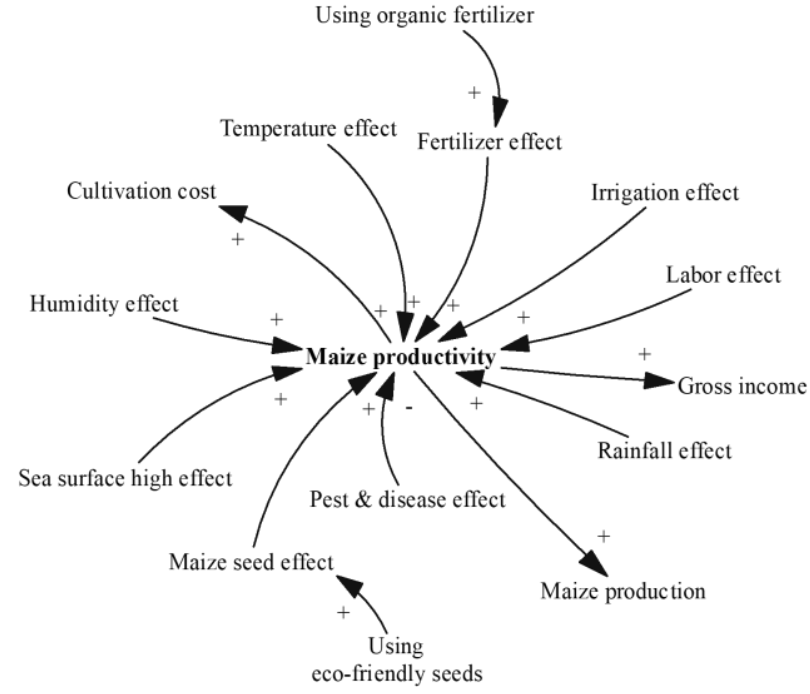

Figure 2. Maize productivity sub-model.

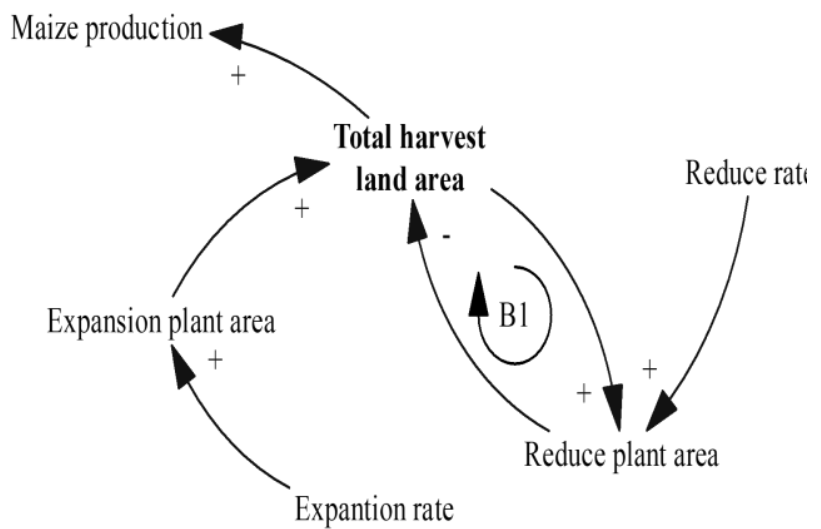

Figure 3. Harvest land area sub-model.

\section{B. Simulation}

Simulations using computer assistance to evaluate a model numerically, and data were collected to estimate the actual characteristics of the model [27]. Very effective simulation models are used for relatively complex systems for analytical solutions to these models. The use of simulations will provide broader insight on the part of management in solving a problem [21].

\section{System Dinamics}

System dynamics was first introduced by Jay W. Forrester at Massachusetts Institute of Technology (MIT), it is a method of solving complex problems that arise due to the tendency of cause and effect of various variables in the system [28]. System dynamics are methods for increasing understanding of complex systems [24]. System dynamics approaches can model a nonlinear behavior and dynamic interactions (feedback) between interrelated variables, it can be handled easily by performing action scenarios or system changes [4]. Up to now, the system dynamics method application has continued to develop since its use in the social fields and physical sciences. 


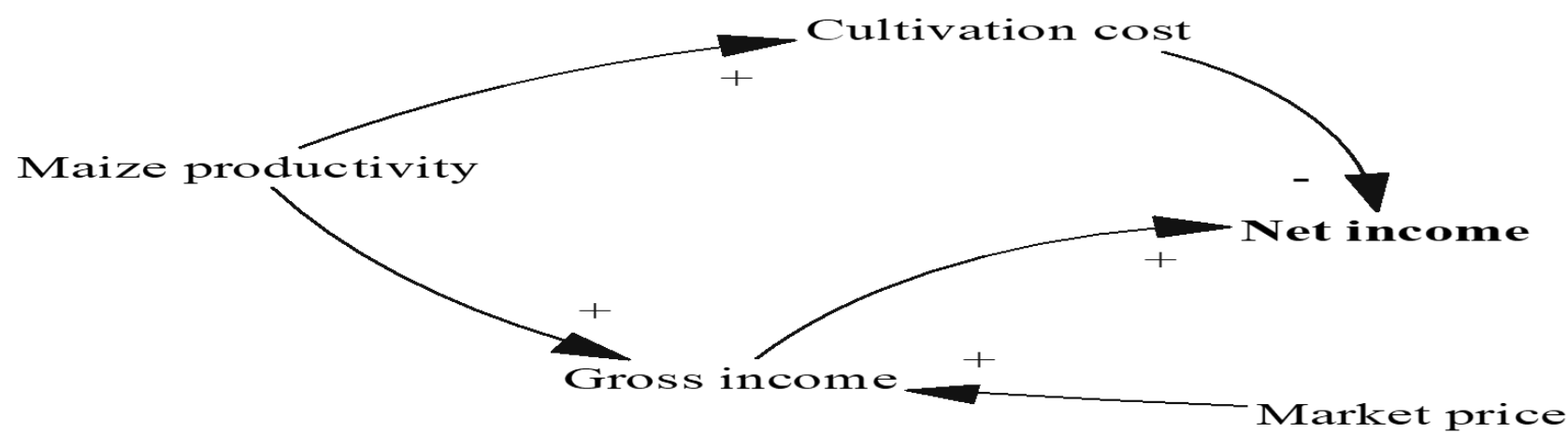

Figure 6. Farmer's income sub-model.

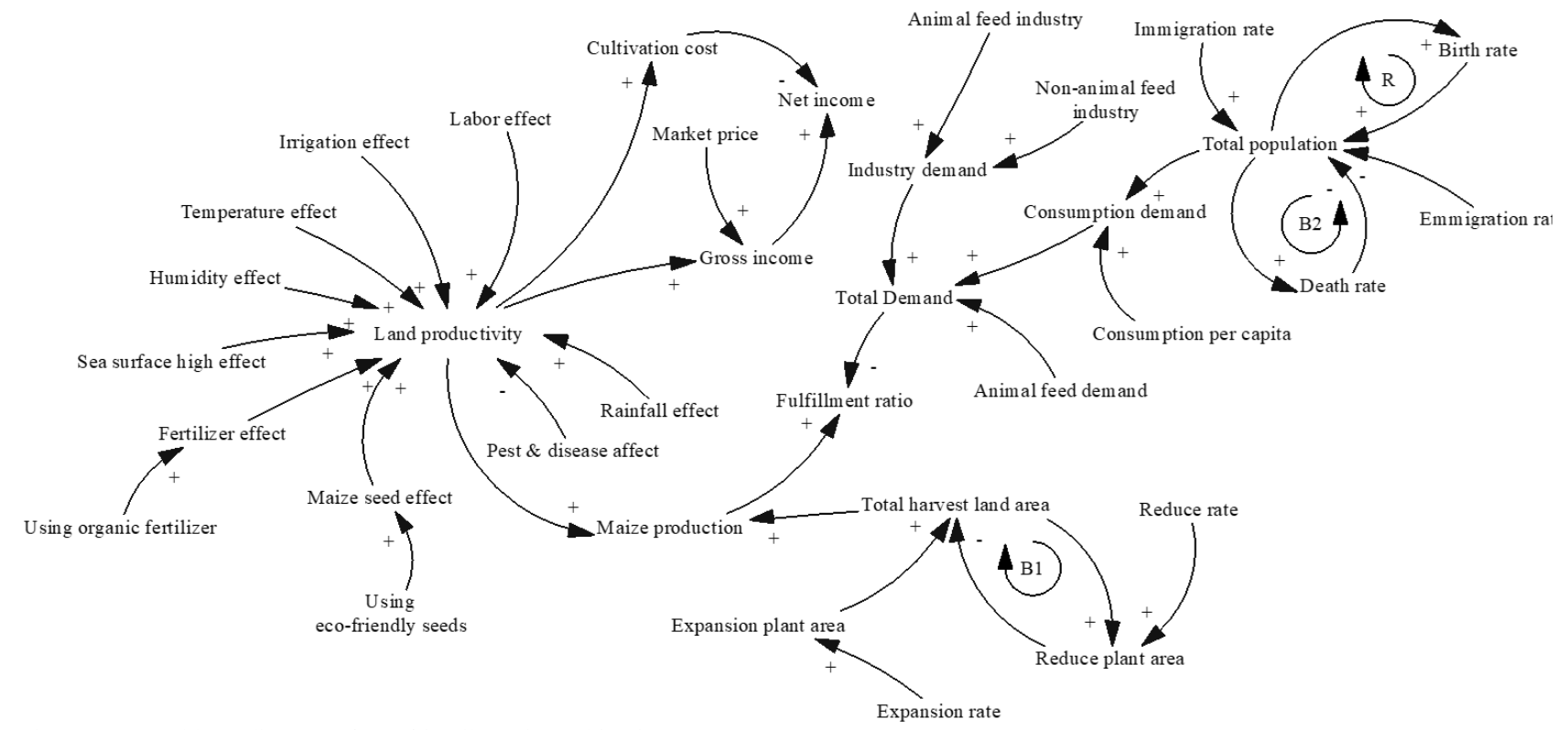

Figure 7. Causal loop diagram of eco-friendly maize cultivation.

\section{Stage of Modeling System Dynamics}

According to Sterman [24], the first stage in the system dynamics approach is to do problem articulation. This stage is done by defining the problem to be solved using a system dynamics model along with defining the variables related therein. At this stage, a literature study is carried out to support this research from related sources such as books, government sites such as BPS (Central Statistics Agency), Ministry of Agriculture, and Ministry of National Development Planning (BAPPENAS), articles in relevant journals or previous research, as well as mass media websites to get information on current maize developments.

The literature data are used as significant variables and auxiliary variables that connected with the problem behavior and affect one another in the system to be modeled and simulated. The basic pattern of the system is used as a diagnostic tool that provides deeper insight into the structure that underlies the system behavior and the events that arise. The results of this literature study identify the factors and problems faced in maize farming system in East Java. The next stage according to Sterman [24] is formulating a dynamics hypothesis. This stage starts with the formulation of a hypothesis that contains the current theory of the temporary problem behavior to form the modeling process. Endogenous focus formulates a dynamics hypothesis that explains the dynamics and endogenous consequences of the feedback structure. In this step, a Causal Loop Diagram (CLD) is made, which is used to describe the relationship of causality between variables in the system.

The last stage is mapping the causation structure based on literature studies using Boundary Adequacy and Causal Loop Diagrams by doing a simulation, dynamic hypothesis will be taken from looking at the structure of relationships between variables. Variables are connected by a causal link, indicated by an arrow. Each causal link is given a polarity, either positive (+) or negative (-) to show how the dependent variable changes when the independent variable changes. In addition, there are also two types of feedback loops in the system dynamics model, they are reinforcement feedback (R) and balance feedback (B) [24]. 
The $6^{\text {th }}$ International Seminar on Science and Technology (ISST) 2020

July $25^{\text {th }}, 2020$, Institut Teknologi Sepuluh Nopember, Surabaya, Indonesia

\section{RESULT AND DISCUSSIONS}

This section presents the results of internal and external factors tat affect maize farming based on literature studies that have been done before, as well as the basic pattern of the system and the relationship of each variable in the causal loop diagram. Results of literature studies from books, government sites such as BPS (Central Statistics Agency), Ministry of Agriculture, and Ministry of National Development Planning (BAPPENAS), articles in relevant journals or previous research, and mass media websites, we obtained internal and external factors that affect the productivity and production of maize in East Java. The following is the result projection of this study:

\section{A. Boundary Adequacy}

Internal and external factors, both significant variables and auxiliar variables that affect each other in making the system dynamics model of maize productivity and production are listed in the boundary adequacy Table 1 .

\section{B. System Basic Pattern}

The basic pattern of the system is used as a diagnostic tool that provides deeper insight into the core structure of the system. Figure 2 describes the basic pattern system for classifying the structure and behavior of a system. In this case, the basic pattern is used to illustrate the effect of maize production on fulfilling demand and the effect of maize productivity on farmer's income. The basic pattern of the system helps in making a detailed sub-model in a causal diagram of the maize production effect. In this case, there are 4 sub-models that must be specified, they are: (1) maize demand and fulfillment ratio, (2) maize productivity, (3) harvest land area, and (4) farmer's income.

\section{Maize Demand and Fulfillment Ratio Sub-Model}

Figure 3 presents a generic structure of maize demand problems. Cause and effect diagram of maize demand to meet consumption needs, animal feed and non-animal feed industries, as well as for animal feed. The fulfillment ratio is influenced by maize production and overall demand for maize. The greater the amount of maize demand, the smaller the fulfillment ratio, and vice versa, the greater the amount of maize production, the greater the fulfillment ratio. Maize demand for consumption is influenced by maize consumption per capita. The population is one of the variables that influence the demand for maize consumption. The population itself is influenced by several factors such as the number of immigrations, the number of emigrations, the birth rate $(\mathrm{R})$, and the death rate (B2).

\section{Maize Productivity Sub-Model}

Figure 4 presents a generic structure of maize productivity problems. There are several factors both internal and external that affect maize productivity. Sub model diagram of cause and effect regarding maize productivity consists of: (1) the use of seed varieties, this has a considerable influence on maize productivity. The use of seeds variable can be used as a scenario to increase the productivity of eco-friendly maize by using hybrid superior seeds. (2) the use of fertilizers to meet nutrient deficiencies in the soil, this is important in increasing maize productivity. The use of fertilizer variable can be used as a scenario of increasing the productivity of eco-friendly maize using organic fertilizer. (3) irrigation canals have function to support irrigation in maize cultivation. (4) labor are the workforces required in the cultivation process that covering almost the entire production process. (5) climate and weather changes, including temperature, humidity, land elevation above sea level, and rainfall. The agricultural sector is very vulnerable to climate change because it affects the amount of production and the quality of yields. (6) pest attack, this could reduce maize productivity.

The amount of maize productivity affects the amount of total maize production and gross income earned by farmers. The greater the maize productivity, the greater the gross income and total production produced. The cost of cultivating maize is determined by the variables that affect its productivity. This can increase the cost of maize cultivation.

\section{E. Harvest Area Sub-Model}

Figure 5 presents the generic structure of the maize harvested area problem. The harvested area of maize is affected by land expansion and land conversion. The land expansion will increase the availability of maize farm. Land expansion is one of the variables that can be used as a scenario of increasing maize productivity by opening new land. Land conversion will reduce the amount of land available for maize farm. The larger the area of maize farm, the greater the intensity of land conversion (B1). Conversion of maize farms are due to changes in land use into housing, industry, and other public facilities. The harvested area affects the total amount of maize production.

\section{F. Farmer's Income Sub-Model}

presents the generic structure of the net income problem of farmers' income. The net income of farmers is influenced by gross income and the cost of maize cultivation. Higher gross income can increase farmers 'net income, while larger cost of cultivation will reduce farmers' net income. The farmer's gross income is influenced by producer-level maize prices and the amount of maize productivity per hectare. While the cost of cultivation is influenced by the overall input costs on maize productivity.

Figure 7 presents a causal loop diagram of the overall interrelationship between the variables of eco-friendly maize cultivation including maize demand and its fulfillment ratio, maize productivity, harvested area, and farmers' income.

\section{CONCLUSION}

Based on the results of analysis and discussion carried out in this study, it can be concluded:(1)The analysis results of ecofriendly maize farming systems produced some important 
information regarding both significant internal and external variables as well as additional variables that support food security; (2)Eco-friendly maize farming system is a system with complex problems involving various interrelated variables in it. This system is influenced by several uncertain variables/patents, linear/nonlinear relationships between variables in the system, and interactive feedback loops; (3)The basic pattern of the system/the system thinking is explained by describing it in a causal loop diagram. The basic pattern of the system can be used to describe the interrelationships between variables and behavior patterns that occur in agricultural systems, especially in improving the quality of eco-friendly maize production. The basic pattern is used as a diagnostic tool in providing a deeper understanding of the problems that arise so it can be used as a basis for policy/scenario making; (4)Constructing a conceptual model (causal loop diagram) using a system dynamics perspective requires in-depth understanding and information on the current condition of agricultural maize commodities, that way the model built can represent the current conditions; (5)The basic pattern of the system/the system thinking described in the conceptual model (causal loop diagram) can be used by the government and stakeholders for decision making in developing strategies and policies related to eco-friendly maize cultivation systems to support food security and for predicting the possibility of unintended consequences in the future; (60From the resulting causal loop diagram, further research can be done by developing several scenarios to predict the state of future maize farming system that can support food security.

\section{REFERENCES}

[1] IK Kariyasa, PH Muliany, AA S, B. Waryanto and D. Riniasri, Outlook for agricultural commodities in the food crop subsector, Jakarta: Center for Agricultural Data and Information Systems of the Ministry of Agriculture, 2018

[2] SR Eckhoff, MR Paulsen and SC Yang, "Maize," Encyclopedia of Food Science and Nutrition, pp. 3647-3653, 2003.

[3] E. Britannica, "Maize plant," 2020. [Online]. Available: https://www.britannica.com/plant/maize-plant. [Accessed March 13, 2020].

[4] JP Walters, DW Archer, GF Sassenrath, JR Hendrickson, JD Hanson, JM Halloran, P. Vadas and VJ Alarcon, "Exploring agricultural production systems and their fundamental components with dynamics modeling systems," Ecological Modeling, vol. 333, pp. 51-65, 2016.

[5] SP Lewi, A. Yunatas, F. Habibie and MA Mustaha, Practical guide to climate smart maize cultivation, Kendari: The Maize Climate Field School (SLI) Team and USAID Climate Change and Resilience Adaptation (APIK), 2019.

[6] M. Aqil, B. Z and NN Andayani, "Innovation of maize adaptation technology to climate change," National Seminar on Agricultural Technology Innovation, pp. 39-48, 2013.

[7] M. Aslam, R. Cengiz and MA Maqbool, Drought stress in maize (Zea mays L.) effects, resistance mechanisms, global achievements and biological strategies for improvement, New York: SpringerBriefs in Agriculture, 2015.

[8] Y. Sulaeman, Maswar and D. Erfandi, "Effect of a combination of organic and inorganic fertilizers on the chemical properties of soils and maize crop yields in acidic drylands," Soil Research Institute, pp. 112, 2017.
[9] Simanjuntak, RR Lahay and E. Purba, "Response of growth and production of shallots (Allium ascalonicum L.) to NPK fertilizer and coffee fruit skin compost," Agroecotechnology Online Journal, vol. 1, no. 3, pp. 362-373, 2013.

[10] J. Chen, S. Lu, Z. Zhang, X. Zhao, X. Li, P. Ning and M. Liu, "Eco friendly fertilizers: A review of materials used and their effects on the environment," Science of the Total Environment, Vols. 613-614, pp. 829-839, 2018.

[11] PK Rai, SS Lee, M. Zhang, YF Tsang and K.-H. Kim, "Heavy metals in food crops: Health risks, fate, mechanisms, and management," Environment International, vol. 125, pp. 365-385, 2019.

[12] H. Azadi and P. Ho, "Genetically modified and organic crops in developing countries: A review of options for food security," Biotechnology Advances, vol. 28, p. 160-168, 2010.

[13] BO Clarke, "Review of 'emerging' organic contaminants in biosolids and assessment of international research priorities for the agricultural use of biosolids," Environ. Int., Vol. 37, pp. 226-247, 2011.

[14] Saumel, I. Kotsyuk, M. Holscher, C. Lenkereit, Weber F and I. Kowarik, "How healthy is urban horticulture in high traffic areas? Trace metal concentrations in vegetable crops from plantings within inner city neighborhoods in Berlin, Germany, "Environ Pollut, vol. 165, pp. 124-132, 2012.

[15] G. Toth, T. Hermann, MR Da Silva and L. Montanarella, "Heavy metals in agricultural soils of the European Union with implications for food safety," Environ. Int., Vol. 88, pp. 299-330, 2016.

[16] PK Rai, Phytoremediation of emerging contaminants in wetlands, Boca Raton, Florida: CRC Press Taylor \& Francis Group, 2018.

[17] CO Dimkpa, J. Andrews, J. Sanabria, PS Bindraban, U. Singh, WH Elmer, JL Gardea-Torresdey and JC White, "Interactive effects of drought, organic fertilizer, and zinc oxide nanoscale and bulk particles on wheat performance and grain nutrient accumulation, "Science of the Total Environment, vol. 722, pp. 1-12, 2020.

[18] Y. Wang, Y. Zhu, S. Zhang and Y. Wang, "What could promote farmers to replace chemical fertilizers with organic fertilizers ?," Journal of Cleaner Production, vol. 199, pp. 882-890, 2018.

[19] H. Wang, J. Xu, X. Liu, D. Zhang, L. Longwei, W. Li and L. Sheng, "Effects of long-term applications of organic fertilizer on improving organic matter content and retarding acidity in red soil from China, "Soil \& Tillage Research, vol. 195, pp. 1-9, 2019.

[20] SM Sadeghi, SA Noorhosseini and CA Damalas, "Environmental sustainability of maize (Zea mays L.) production on the basis of nitrogen fertilizer applications: The case of Lahijan, Iran," Renewable and Sustainable Energy Reviews, vol. 95, pp. 48-55, 2018.

[21] E. Suryani, Modeling and Simulation, Graha Ilmu, 2005.

[22] B. Kopainsky, G. Hager, H. Herrera and PH Nyanga, "Transforming food systems at local levels: Using participatory systems dynamics in an interactive manner to refine small-scale farmers' mental models," Ecological Modeling, vol. 362, pp. 101-110, 2017.

[23] CW Churchman, The systems approach, New York: Dell Publishing Co., Inc., 1968.

[24] JD Sterman, Business Dynamics: System Thinking and Modeling for a Complex World, McGraw-Hill / Irwin: Jeffrey J. Shelstad, 2000.

[25] Ford, Modeling the environment: an introduction to system dynamics models of environmental systems, Island Press, 1999.

[26] GP Richardson and LP A, Introduction to dynamics modeling systems with dynamo, Cambridge, Massachusetts, and London, England: The MIT Press, 1986.

[27] AM Law and WD Kelton, Simulation modeling and analysis, 2nd edition ed., McGraw-Hili, 1991.

[28] JW Forrester, System dynamics: the foundation under system thinking, Cambridge, MA 02139: MIT's Sloan School of Management, 1999.

[29] AB Putra, S. Mukaromah and PM Kusumantara, "Analysis of the Maize Systems to Increase Production with a Dynamic System Approach," Surabaya, 2018.

[30] Food Security Agency, "Maize cultivation," NAD Institute for Agricultural Technology Study, Aceh, 2009.

[31] PA Hariwibowo, R. Anindita and Suhartini, "The Evaluation of Indonesia Import Policies of Garlic," Greener Journal of Business and Management Studies, vol. 5, no. 1, pp. 16-30, 2015. 
The $6^{\text {th }}$ International Seminar on Science and Technology (ISST) 2020

July $25^{\text {th }}, 2020$, Institut Teknologi Sepuluh Nopember, Surabaya, Indonesia

[32] Muslim, "Climate change mitigation in maintaining rice productivity in rice fields (cases; regulation of Indramayu)," Journal of Applied Agriculture Research, vol. 13, no. 3, pp. 211-222, 2013.

[33] TM d. P. Tanure, DN Miyajima, AS Magalhaes, EP Domingues and TS Carvalho, "The impacts of climate change on agricultural production, land use and economy of the legal Amazon region between 2030 and 2049," Economia, pp. 1-19, 2020.

[34] Li, Y. Xiong, Z. Cui, Q. Huang, W. Han and G. Huang, "The effects of irrigation and fertilization regimes on grain yield, water and nitrogen productivity of mulching cultivated maize (Zea mays L.) in the Hetao Irrigation District of China, "Agricultural Water Management, vol. 232, pp. 1-12, 2020.

[35] J. Wang, S. Guo, S. Kang, Y. Wang, T. Du and L. Tong, "Joint optimization of irrigation and planting patterns to guarantee seed quality, maximize yield, and save water in hybrid maize seed production," European Journal of Agronomy, vol. 113, pp. 1-14, 2020.

[36] M. Hafidh, "The effect of labor, capital and land area on the production of lowland rice farming," Department of Development Economics, Semarang State University, Semarang, 2009.

[37] Y Y. L. Seran, "Development of organic maize farming systems in an effort to increase farmers' income in dry land," BPTP East Nusa Tenggara, TTS Regency, 2005.

[38] W. Li, B. Clark, JA Taylor, H. Kendall, G. Jones, Z. Li, S. Jin, C. Zhao, G. Yang, C. Shuai, X. Cheng, J. Chen, H. Yang and LJ Frewer, "A hybrid modeling approach to understanding the adoption of precision agriculture technologies in Chinese cropping systems," Computers and Electronics in Agriculture, vol. 172, pp. 1-12, 2020.

[39] Nababan, Analysis of the factors that affect rice farmers' income in the three sub-districts of Karaga regency, Medan: USU Press, 2009.

[40] Sayifullah and Emmalian, "The influence of agricultural sector labor and agricultural sector government spending on the gross domestic product of the agricultural sector in Indonesia," JEQu (Journal of Economics), vol. 8, no. 1, pp. 66-81, 2018.
[41] CY Bora and B. Murdolelono, "Influence of fertilizing to ahuklean maize cultivation in Besikama, Belu, NTT," Biology News, vol. 8, no. 1, pp. 53-59, 2006.

[42] F. Hernanto, Farming Science, Jakarta: Self-Helping Spreaders, 1996.

[43] Ministry of Agriculture, "Local governments to be wise conversion of productive agricultural land," 2020. [Online]. Available: https://www.pertanian.go.id/home/?show=news\&act=view\&id=2334. [Accessed March 13, 2020].

[44] JP Ambarita and IN Kartika, "Influence of land area, use of pesticides, labor, fertilizer on coffee production in Jembrana regency sub-district," E-Journal of Development Economics, Udayana University, vol. 4, no. 7, pp. 776-793, 2015.

[45] Soekartawi, Agribusiness theory and its application, Jakarta: Raja grafindo Persada, 1999.

[46] G. Soullier and P. Moustier, "Impacts of contract farming in domestic grain chains on farmer income and food insecurity. Contrasted evidence from Senegal," Food Policy, pp. 1-20, 2018.

[47] D. Gervantes-Godoy, S. Kimura and J. Anton, Smallholder risk management in developing countries, 16th ed., OECD Publishing, 2013.

[48] Z. Wang, X. Deng and J. Chen, "Impacts of sparing use of water on farmer income from China," Physics and Chemistry of the Earth, Vols. 89-90, pp. 18-24, 2015.

[49] T. Reardon, C. Barrett, J. Berdegue and J. Swinnen, "Agrifood industry transformation and small farmers in developing countries," World Dev, vol. 37, pp. 1717-1727, 2009.

[50] Z. Xu, L. Yao and X. Chen, "Urban water supply system optimization and planning: Bi-objective optimization and system dynamics methods," Computers \& Industrial Engineering, vol. 142, pp. 1-13, 2020.

[51] Suwandi, L. Nuryati, B. Waryanto, Akbar, R. Widaningsih and M. Chafid, Outlook for agricultural commodities in the maize food crops sub-sector, Jakarta: Center for Agricultural Data and Information Systems Ministry of Agriculture, 2016.

[52] S. Purwanto, "Development of Production and Policies in Increasing Maize Production," Directorate of Cereals Cultivation, Directorate General of Food Crops, pp. 456-461, 2007. 